\title{
Highly active Cu-ZnO catalysts for the WGS reaction at medium-high space velocities: effect of the support composition
}

\author{
C. Price ${ }^{a}$, L. Pastor-Pérez ${ }^{b *}$, E. le Sachéa ${ }^{a}$ A. Sepúlveda-Escribano ${ }^{b}$ and T. R. Reina ${ }^{a *}$ \\ ${ }^{\text {a }}$ Department of Chemical Engineering and Process Engineering, University of Surrey Guildford, GU2 \\ 7XH, United Kingdom. \\ ${ }^{\mathrm{b}}$ Laboratorio de Materiales Avanzados, Departamento de Química Inorgánica - Instituto Universitario \\ de Materiales de Alicante Universidad de Alicante, Apartado 99, E-03080 Alicante, Spain.
}

$\left(^{*}\right)$ corresponding authors: laura.pastor@ua.es, t.ramirezreina@surrey.ac.uk

\begin{abstract}
Cu-ZnO based catalysts are the benchmark materials for the low-temperature WGS reaction. However, they present a crucial drawback which limits their application in portable devices: they only work under very low space velocities. In this study, we have developed a series of multicomponent $\mathrm{Cu}-\mathrm{ZnO}$ catalysts able to work at relatively high space velocities with outstanding activity and stability. Different reference supports have been utilised with $\mathrm{CeO}_{2}$ $\mathrm{Al}_{2} \mathrm{O}_{3}$ being the most promising system. Overall, this work describes a strategy to design advanced Cu-based catalysts that can overcome the residence time restrictions in the WGS reaction.
\end{abstract}

Keywords:Cu catalysts, space velocity, hydrogen fuel processors, WGS, cerium oxide.

\section{Introduction}

Hydrogen powered fuel cells are meant to play a pivotal role in the new global energy paradigm which pursues a shift towards low-carbon technologies. Hydrogen is typically produced from reforming reactions with the unavoidable generation of carbon monoxide, which is a harmful gas for the anode of the polymer electrolyte membrane fuel cells (PEMFC). Therefore, the production of hydrogen pure enough to feed a PEM-FC involves a series of fuel processing reactions including hydrocarbon or biomass reforming, water-gas shift (WGS) reaction, preferential CO-oxidation and/or methanation. Among these processes the 
WGS is the most crucial unit for $\mathrm{H}_{2}$ clean up since it faces the highest amount of $\mathrm{CO}$. The commercial catalysts for the water-gas shift reaction at low temperatures are mixtures of $\mathrm{Cu}$ and $\mathrm{ZnO}$ supported on alumina [1-15]. This formulation has remained almost unchangeable in the past decades. Indeed, despite its drawbacks (i.e. they are pyrophoric and they require previous activation) copper-based catalysts provide better activity/cost balance than noble metal-based systems such as Pt and $\mathrm{Au}$, which have been intensively applied in this reaction [4-13].

The copper-based catalyst is an excellent formulation for static applications, but the implementation of the WGS units in fuel processors for portable applications imposes a limit in the reactor volume. This is the "Achiles heel" of the $\mathrm{Cu}-\mathrm{ZnO} / \mathrm{Al}_{2} \mathrm{O}_{3}$ catalysts, which for practical reasons are utilised in pellets to provide enough mass to avoid poisoning and increase the lifespan of the catalysts, thus resulting in very low space velocities (e.g. 2000$4000 \mathrm{~h}^{-1}$ ) and making necessary big reactor volumes [2]. In response to this need, this work aims to develop high performance $\mathrm{Cu}-\mathrm{ZnO}$ catalysts able to operate at medium-high space velocities in order to overcome the volume restrictions that limit the application of these cost-effective materials in portable devices. Also, given the well documented importance of the support in the shift reaction [14-21], four reference supports have been selected in this paper to determine their effect on the WGS activity when working beyond the typical low space velocity range.

\section{Experimental}

\subsection{Catalyst preparation}

Experimental details on catalysts preparation are reported in the Supporting Info. Briefly, the samples are composed of $15 \mathrm{wt} . \% \mathrm{CuO}$ and $5 \mathrm{wt} . \% \mathrm{ZnO}$ finely dispersed on the support $\left(\mathrm{Al}_{2} \mathrm{O}_{3}\right.$ - Sasol; $\mathrm{CeO}_{2}-\mathrm{Al}_{2} \mathrm{O}_{3}$ - Puralox, Sasol; $\mathrm{SiO}_{2}$ - CARiACT Q-6 and ZSM-5 ammonium, 23:1 mol $\mathrm{SiO}_{2}: \mathrm{Al}_{2} \mathrm{O}_{3}-$ AlfaAesar). The variety of supports provides a complete picture of the carrier influence. In fact, they have been intentionally selected given their disparity in terms of textural properties (see Table S1 supporting info), redox behaviour and acid/base features.

\subsection{Characterization}


The physicochemical characterisation of the samples was determined by X-Ray diffraction (XRD), temperature-programed reduction (TPR) experiments and Raman spectroscopy. (see Supporting Information for more details).

\subsection{Catalytic activity and selectivity}

The catalytic conditions, calculations and a detailed description of the equipment can be found in the Supporting Information.

\section{Results and discussion}

Figure 1 shows the catalytic screening in the WGS reaction of the prepared catalysts in a model WGS mixture at $9000 \mathrm{~h}^{-1}$ (more than four times the space velocity in industrial stationary applications $\sim 2000 \mathrm{~h}^{-1}$ ). The plot clearly reveals the effect of the support in the catalytic activity. While the catalysts supported on $\mathrm{SiO}_{2}$ and ZSM-5 zeolite are not able to fully abate $\mathrm{CO}$, the solids supported on $\mathrm{Al}_{2} \mathrm{O}_{3}$ and $\mathrm{CeO}_{2}-\mathrm{Al}_{2} \mathrm{O}_{3}$ reach full conversion at 300 and $225^{\circ} \mathrm{C}$ respectively. This is an excellent result especially when compared with the commercial catalyst's activity (adapted from ref [22]) and tested at much lower space velocity. Indeed, the harsh residence time utilised in the catalytic tests highlights the importance of the achieved results. Even more remarkable is the extraordinary CO conversion levels reached by the $\mathrm{Cu}-\mathrm{ZnO} / \mathrm{CeO}_{2}-\mathrm{Al}_{2} \mathrm{O}_{3}$ sample, with total $\mathrm{CO}$ conversion at rather low temperature. Yet, this catalyst outperforms the activity of Cu-based systems promoted with $\mathrm{Au}$ and measured at lower spaces velocities as those recently reported elsewhere [21].

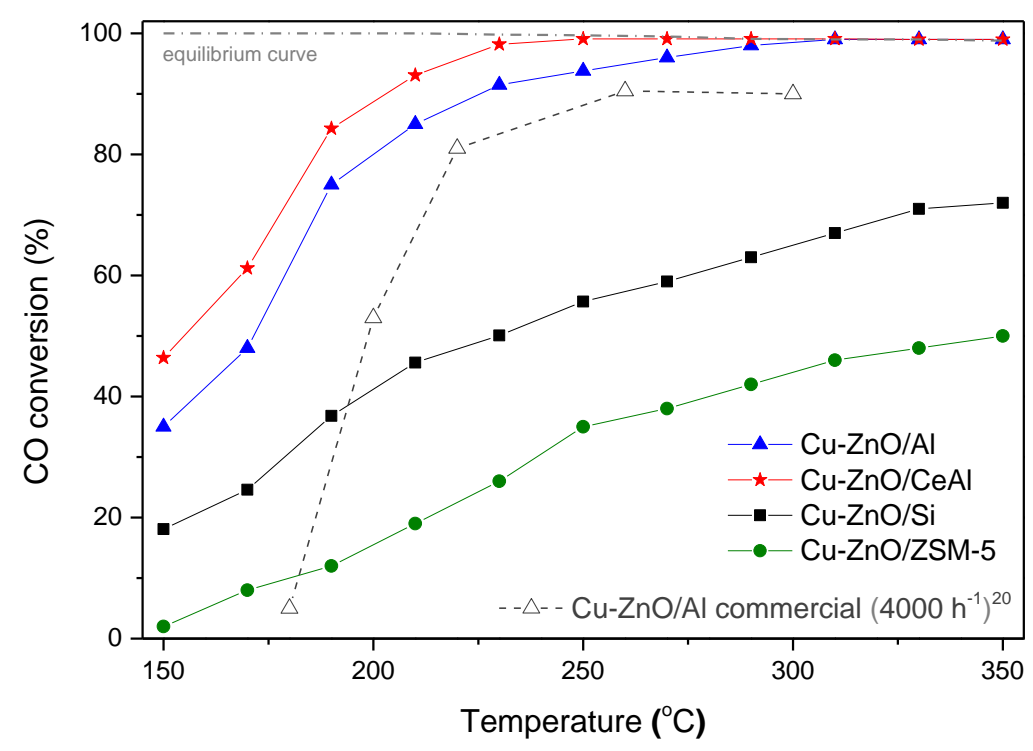


Figure 1. Catalytic activity in a model WGS mixture $\left(4.5 \% \mathrm{CO}, 30 \% \mathrm{H}_{2} \mathrm{O}\right.$ in $\mathrm{He}$ at $\left.9000 \mathrm{~h}^{-1}\right)$.

In order to establish a more general comparison with previously reported highly active shift catalysts, the reaction rates at $180^{\circ} \mathrm{C}$ were calculated and presented in Table 1. As shown in the table, the $\mathrm{Cu}-\mathrm{ZnO} / \mathrm{CeO}_{2}-\mathrm{Al}_{2} \mathrm{O}_{3}$ and $\mathrm{Cu}-\mathrm{ZnO} / \mathrm{Al}_{2} \mathrm{O}_{3}$ catalysts are much better systems than the reference commercial $\mathrm{CuO}-\mathrm{ZnO}$ catalyst reported in literature. Furthermore, our catalysts are clearly superior to noble metal-based catalysts tested at much lower space velocities, what reinforces the exceptional behaviour of the developed system.

Table 1. WGS reaction rates at $180^{\circ} \mathrm{C}$ normalised per mol of active phase $(\mathrm{Cu}, \mathrm{Au}$ and $\mathrm{Pt}$ were considered as active phases)

${ }^{1}$ : Data obtained from Figure 2 (post reforming WGS conditions)

For a practical application in hydrogen clean-up goals, the most active catalysts were tested under a realistic WGS mixture (including $\mathrm{CO}_{2}$ and $\mathrm{H}_{2}$ ). The results (Figure 2) reveal that despite the expected shift of the conversion curve towards higher temperature (as a direct consequence of Le Chatelier principle) the $\mathrm{Cu}-\mathrm{ZnO} / \mathrm{CeO}_{2}-\mathrm{Al}_{2} \mathrm{O}_{3}$ catalyst presents elevated $\mathrm{CO}$ conversion levels and showing much better conversion than the $\mathrm{Cu}-\mathrm{ZnO} / \mathrm{Al}_{2} \mathrm{O}_{3}$ sample. For further comparison, catalytic data of commercial samples tested in fairly similar reaction mixtures available in literature have been included in Figure 2. For example in the paper by Mendes and co-workers [25], they studied a commercial catalyst (green line) which is more active than our homemade systems (blue lines in the Figure 2). However, this catalyst was tested at much lower space velocity than ours. On the other hand, Pingjun et al. [26] prepared a commercial-like copper catalyst able to work at rather high space velocity (red line) with

\begin{tabular}{|c|c|c|c|}
\hline Sample & $\begin{array}{c}\text { WGS rates }(\mathrm{mol} \mathrm{CO} \\
\text { converted } / \mathrm{s}^{*} \mathrm{~mol} \text { active } \\
\text { phase } \times 10^{4}\end{array}$ & GHSV $\left(h^{-1}\right)$ & $\begin{array}{c}\text { WHSV } \\
\left(\mathrm{mLg}^{-1} \mathrm{~h}^{-1}\right)\end{array}$ \\
\hline $\mathrm{Cu}-\mathrm{ZnO} / \mathrm{Al}_{2} \mathrm{O}_{3}$ & 20.4 & 9000 & 12000 \\
\hline $\mathrm{Cu}-\mathrm{ZnO} / \mathrm{CeO}_{2}-\mathrm{Al}_{2} \mathrm{O}_{3}$ & 26.5 & 9000 & 12000 \\
\hline $\mathrm{Cu}-\mathrm{ZnO} / \mathrm{SiO}_{2}$ & 10.9 & 9000 & 12000 \\
\hline $\mathrm{Cu}-\mathrm{ZnO} / \mathrm{ZSM}-5$ & 3.5 & 9000 & 12000 \\
\hline commercial CuO-ZnO/ $/ \mathrm{Al}_{2} \mathrm{O}_{3}[22]$ & 0.8 & 4000 & - \\
\hline $\mathrm{CuCe}_{0.95} \mathrm{Zn}_{0.05}[22]$ & 21.7 & 4000 & - \\
\hline $\mathrm{Au} / \mathrm{CeO}_{2}-\mathrm{CuO}[21]$ & 1.3 & 4000 & 6000 \\
\hline $\mathrm{Pt} / \mathrm{Al}_{2} \mathrm{O}_{3}[23]$ & 5.1 & 4000 & 6000 \\
\hline $\mathrm{Cu}-\mathrm{ZnO} / \mathrm{Al}_{2} \mathrm{O}_{3}$ hydrotalcite[24] & 0.2 & 4000 & 6000 \\
\hline $\mathrm{Au} / \mathrm{Cu}-\mathrm{ZnO} / \mathrm{Al}_{2} \mathrm{O}_{3}$ hydrotalcite [24] & 6.3 & 4000 & 6000 \\
\hline${ }^{1} \mathrm{Cu}-\mathrm{ZnO} / \mathrm{CeO}_{2}-\mathrm{Al}_{2} \mathrm{O}_{3}$ & 10.3 & 9000 & 12000 \\
\hline 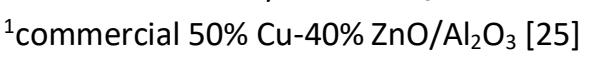 & 9.2 & - & 4800 \\
\hline${ }^{1}$ commercial $42 \% \mathrm{Cu}-\mathrm{ZnO} / \mathrm{Al}_{2} \mathrm{O}_{3}[26]$ & 4.9 & 30000 & - \\
\hline
\end{tabular}

elevated conversions at low temperature. These two commercial systems seem to 
outperform the activity of our catalysts. Nevertheless, the main advantage of our catalysts must be mentioned at this point, and this is the very low $\mathrm{Cu}$ loading compared to the typical commercial systems (i.e. the catalysts in this study present $15 \mathrm{wt} . \% \mathrm{Cu}$ while the commercial catalysts are in the 40-50 wt.\% range of $\mathrm{Cu}$ ). The balance low copper loading/high performance highlights the potential impact of our catalysts in the WGS reaction. Indeed, if the apparent reaction rates are calculated (Table 1 ) the superiority of our catalysts becomes clearer.

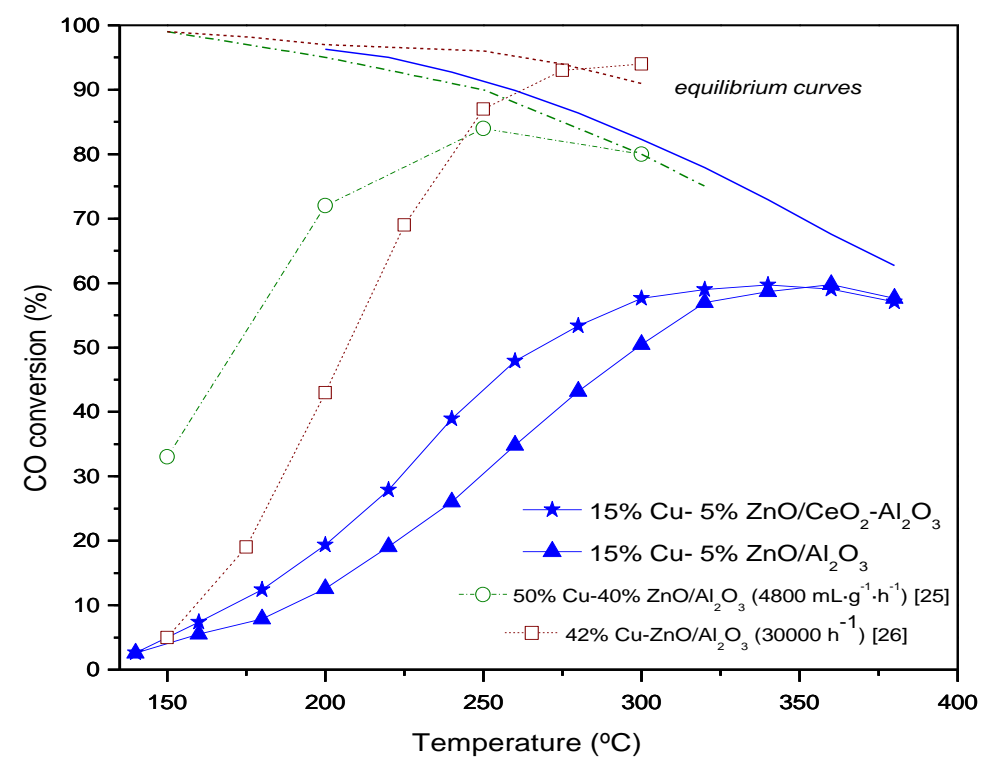

Figure 2.Catalytic activity comparison of our samples $\left(25 \% \mathrm{H}_{2} \mathrm{O}+8 \% \mathrm{CO}+37 \% \mathrm{H}_{2}+8 \% \mathrm{CO}_{2}\right)$, a $50 \% \mathrm{Cu}-40 \% \mathrm{ZnO} / \mathrm{Al}_{2} \mathrm{O}_{3}$ commercial sample $\left(16.90 \% \mathrm{H}_{2} \mathrm{O}+4.75 \% \mathrm{CO}+28.46 \% \mathrm{H}_{2}+10.06 \%\right.$ $\left.\mathrm{CO}_{2}\right)[25]$ and a commercial-like $42 \% \mathrm{Cu}-\mathrm{ZnO} / \mathrm{Al}_{2} \mathrm{O}_{3}$ sample $\left(27 \% \mathrm{H}_{2} \mathrm{O}+11 \% \mathrm{CO}+26 \% \mathrm{H}_{2}+7 \%\right.$ $\left.\mathrm{CO}_{2}\right)[26]$ in a post-reforming WGS mixture.

Furthermore, this catalyst displayed great stability showing just small activity depletion (from $38 \%$ to $31 \%$ CO conversion) after working for more than 160 hours of continuous operation under realistic conditions (Figure 3). In addition, when portable applications are targeted, the catalysts in the WGS unit must withstand eventual star-up/shutdowns situations [26, 27]. This kind of stability experiments are the most demanding tests for a WGS catalyst since during the cooling down, liquid water may condensate on the pores of the catalysts causing severe deactivation. However, as pictured in Figure 3, our $\mathrm{Cu}-\mathrm{Zn} / \mathrm{CeO}_{2}-\mathrm{Al}_{2} \mathrm{O}_{3}$ catalyst is rather robust towards start/stop cycles. The first contact with liquid water dropped the CO conversion to $24 \%$ but after 4 cycles the conversion was stabilised at $20 \%$ (it should be mentioned that the cycles were conducted right after the long term stability test). A similar test was carried out for the $42 \% \mathrm{Cu}-\mathrm{Zn} / \mathrm{Al}_{2} \mathrm{O}_{3}$ catalysts in ref [26]. Herein, they observed that 
after only 7 hours of stability test and 4 start/stop cycles the conversion drops drastically to $20 \%$. In contrast, we run our stability during $160 \mathrm{~h}$ (long term test) plus 12 hours of start/stop cycles showing better results than those exhibited by the commercial catalysts. The later, emphasises the suitability of this catalyst for direct application in integrated reforming-WGS fuel processors. Indeed, as stated by Farrauto et al. the commercial CuZn WGS catalyst suffers for irreversible loss of activity upon exposure to liquid water during start-up and shut-down cycles and cannot be regenerated [28]. Indeed, partial oxidation of copper and/or sintering of the metallic phase could happen. However, the post reaction XRD (Figure S2 and Table S2 supporting info) reveals that Cu remains as metallic after the standard runs and also after the stability tests. Furthermore, sintering does not seem to be important for these catalysts. A slight increase in the $\mathrm{Cu}$ particle size was detected for the $\mathrm{Cu}-\mathrm{Zn} / \mathrm{Al}_{2} \mathrm{O}_{3}$ while the $\mathrm{Cu}$ $\mathrm{ZnO} / \mathrm{CeO}_{2}-\mathrm{Al}_{2} \mathrm{O}_{3}$ maintains its copper particle size almost constant even after the stability tests. The later reveals the role of ceria: it not only promotes the catalytic activity but also improves the stability.

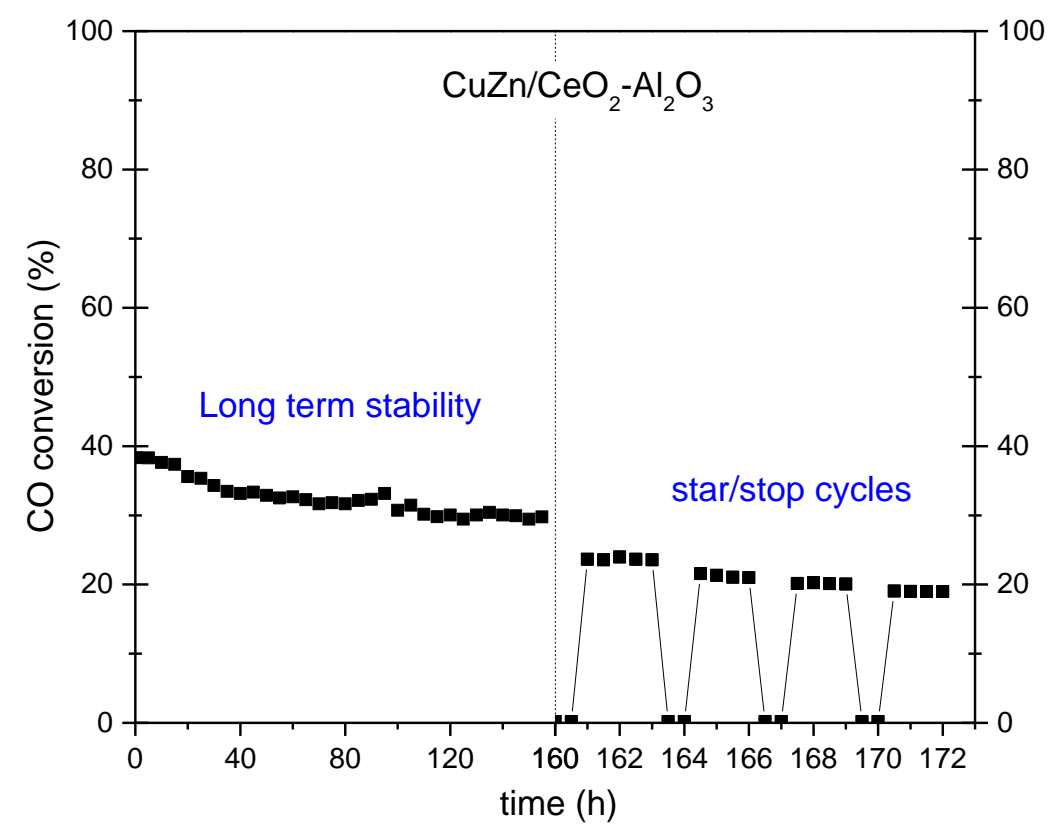

Figure 3. Long-term stability test and start-up/shutdowns study at $250^{\circ} \mathrm{C}$ and post-reforming WGS mixture at $9000 \mathrm{~h}^{-1}$

The physicochemical characterisation provides some clues to explain the superior activity of the $\mathrm{Cu}-\mathrm{ZnO} / \mathrm{CeO}_{2}-\mathrm{Al}_{2} \mathrm{O}_{3}$ catalyst over the other systems included in this study. The XRD patterns (Figure S1 supporting info) indicate the presence of crystalline $\mathrm{CuO}$ species after calcination. Some peaks related to the different supports have been detected (e.g. diffraction 
lines of $\mathrm{CeO}_{2}$ fluorite cubic cell for the $\mathrm{CeO}_{2}-\mathrm{Al}_{2} \mathrm{O}_{3}$ support and zeolite peaks for the system supported on ZSM-5). No diffraction signals related to $\mathrm{ZnO}$ were found, pointing a good dispersion of this oxide in all the samples. As for the Raman analysis (Figure S2, supporting info) all the samples presented the main Raman modes of cupric oxide $\left(A_{1 g}+2 B_{g}\right)$ at $275 \mathrm{~cm}^{-}$ ${ }^{1}, 330 \mathrm{~cm}^{-1}$ and $619 \mathrm{~cm}^{-1}$ as described by Xu et al [29]. Herein, the ceria based sample present an additional Raman mode at $442 \mathrm{~cm}^{-1}$ which can be attributed to the symmetric breathing mode, $\mathrm{F}_{2 g}$, of the oxygen atoms surrounding the $\mathrm{Ce}^{4+}$ ions in the fluorite structure [30]. The presence of ceria in close contact with $\mathrm{CuO}$ results in electronic perturbations and creation of surface defects in both oxides, making the $\mathrm{CuO} / \mathrm{CeO}_{2}$ interface an ideal reactive site for $\mathrm{CO}$ and $\mathrm{H}_{2} \mathrm{O}$ in the shift reaction, as reported elsewhere [21]. Indeed, the band at $560 \mathrm{~cm}^{-1}$ observed in this sample is associated to oxygen vacancies - Ov - confirming the presence of oxygen defects in ceria.

The redox properties of the catalysts were studied by means of $\mathrm{H}_{2}$-TPR, and the results are presented in Figure 4 The simplest profile was obtained for the $\mathrm{Cu}-\mathrm{ZnO} / \mathrm{Al}_{2} \mathrm{O}_{3}$ sample, which only presented one reduction zone centred at $268^{\circ} \mathrm{C}$ associated to the reduction of $\mathrm{CuO}$ to metallic $\mathrm{Cu}$, as previously indicated by Shishido et al. [31]. The catalysts supported on $\mathrm{SiO}_{2}$ and ZSM-5 presented two reduction zones, indicating the presence of different types of $\mathrm{CuO}$ particles and $\mathrm{CuO}$-support interactions. As for the $\mathrm{Cu}-\mathrm{ZnO} / \mathrm{CeO}_{2}-\mathrm{Al}_{2} \mathrm{O}_{3}$ catalyst, two reduction zones with a shoulder in the second one were found. This profile accounts for the reduction of $\mathrm{CuO}$ and probably the simultaneous reduction of $\mathrm{CeO}_{2}$ surface species [21]. The parallel reduction of $\mathrm{CuO}$ and $\mathrm{CeO}_{2}$ indicates an intimate $\mathrm{Cu}-\mathrm{CeO}_{2}$ contact, in fair agreement with the Raman results. Indeed, according to the TPR profile, the pre-reduction treatment before every catalytic run results in full reduction of $\mathrm{Cu}$ and partial reduction of $\mathrm{CeO}_{2}$, thus leading to a $\mathrm{Cu}-\mathrm{ZnO} / \mathrm{CeO}_{2-\mathrm{x}}$ system supported on alumina. This configuration is key to understand the exceptional behaviour of this catalyst. As stated by Rodriguez's group, $\mathrm{Cu} / \mathrm{CeO}_{2-\mathrm{x}}$ (and the inverse $\mathrm{CeO}_{2-x} / \mathrm{Cu}$ ) are excellent catalysts for the shift reaction where the oxygen vacancies on ceria play a critical role for water activation (the rate limiting step) [18, 32]. Furthermore, the oxygen mobility of ceria linked to its extensive oxygen storage capacity converts cerium oxide in the ideal promoter for a redox reaction such as the WGS [21]. On the other hand, $\mathrm{Cu}-\mathrm{ZnO} / \mathrm{Al}_{2} \mathrm{O}_{3}$ is a benchmark catalyst for this reaction. As a result, the outstanding performance of our multicomponent $\mathrm{Cu}-\mathrm{ZnO} / \mathrm{CeO}_{2}-\mathrm{Al}_{2} \mathrm{O}_{3}$ catalyst is just the careful combination of the excellent skills of $\mathrm{Cu}-\mathrm{ZnO} / \mathrm{Al}_{2} \mathrm{O}_{3}$ plus the redox promotion introduced by 
ceria. The later also eases the reaction barrier via water activation on its oxygen vacancies, which formation is favoured due to the intimate $\mathrm{CuO}-\mathrm{CeO}_{2}$ interaction.

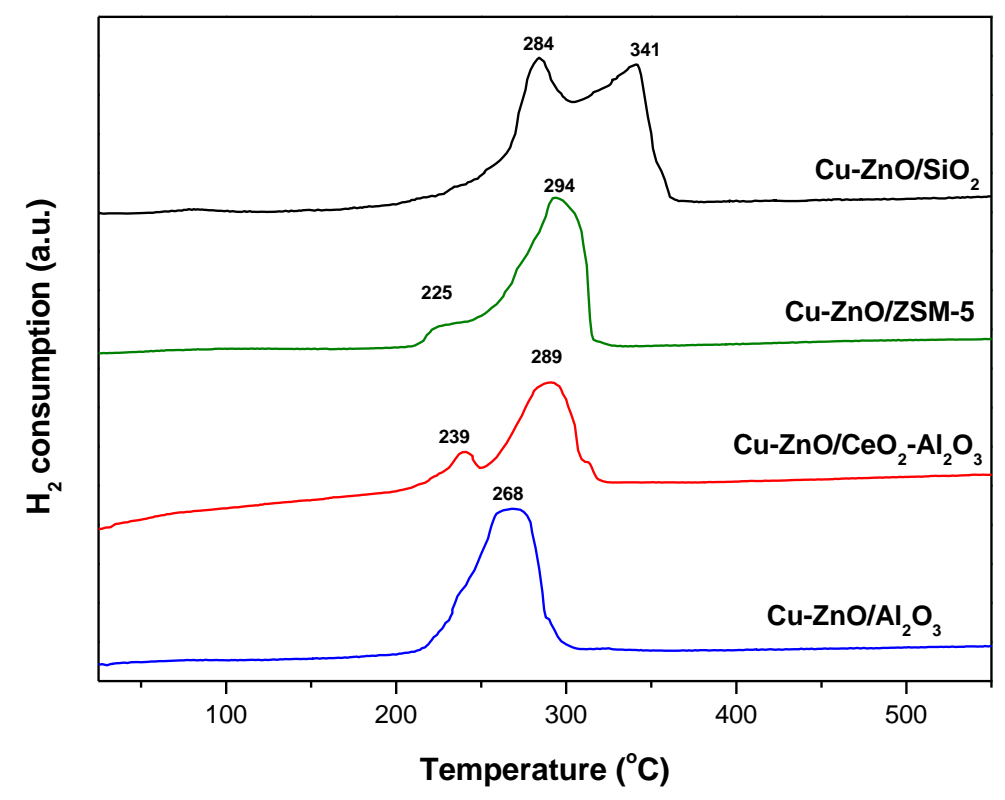

Figure 4. $\mathrm{H}_{2}$-TPR profiles.

\section{Conclusions}

The redox and structural promotion described above has been successfully incorporated in this paper to jump the space velocity limitations of the Cu based catalysts in the shift reaction. Somehow our results connect the physical chemistry knowledge in $\mathrm{CeO}_{2}$ promoted $\mathrm{Cu}$ catalysts with the engineering needs of hydrogen fuel processors.

Overall, the developed $\mathrm{Cu}$ based catalysts are able to work successfully at relatively high spaces velocities in close to real conditions for portable applications. This kind of catalysts outperforms the catalytic activity of state of the art materials reported so far, some of them based on noble metals. Yet more, the excellent catalytic behaviour displayed by our $\mathrm{Cu}$ $\mathrm{ZnO} / \mathrm{CeO}_{2}-\mathrm{Al}_{2} \mathrm{O}_{3}$ catalyst is reinforced by its high stability and tolerance to start/stop situations which seems to be associated to the presence of ceria avoiding copper oxidation and sintering. Currently, further investigations are on-going in our labs to expand the evidences in the observed performance. In any case, the design strategy presented herein opens new avenues for research in cost-effective and highly performing catalysts for the hydrogen economy.

\section{Acknowledgements}


Financial support for this work was provided by the Department of Chemical and Process Engineering at the University of Surrey. The Spanish team acknowledges Ministerio de Economía, Industria y Competitividad of Spain (Project MAT2013-45008-P). Sasol and Fuji Silysia Chemical Ltd are kindly acknowledged for providing the supports.

\section{References}

[1] Lloyd L, Ridler DE, Twigg MV. The water gas shift reaction. In Twigg MV. Catalyst Handbook. 2nd ed. London: Manson Pub.; 1996, p. 283-338.

[2] Ratnasamy C, Wagner. Water Gas Shift Catalysis. JP. Catal. Rev. 2009; 51: 325-440.

[3] Li D, Cai Y, Ding Y, Li R, Lu M, Jiang L. Layered double hydroxides as precursors of Cu catalysts for hydrogen production by water-gas shift reaction. Int. J. Hydrogen Energy 2015; 40: 10016-10025.

[4] Andreeva D, Idakiev V, Tabakova T, Andreev A. Low-Temperature Water-Gas Shift Reaction over $\mathrm{Au} / \alpha-\mathrm{Fe}_{2} \mathrm{O}_{3}$. J. Catal. 1996; 158: 354-355.

[5] Farrauto RJ, Liu Y, Ruettinger W, Ilinich O, Shore L, Giroux T. Precious Metal Catalysts Supported on Ceramic and Metal Monolithic Structures for the Hydrogen Economy. Catal. Rev. 2007; 49: 141-196.

[6] Jacobs G, Ricote S, Patterson PM, Graham UM, Dozier A, Khalid S, Rhodus E, Davis BH. Low temperature water-gas shift: Examining the efficiency of $\mathrm{Au}$ as a promoter for ceriabased catalysts prepared by CVD of a Au precursor. Appl. Catal. A 2005; 292: 229-243.

[7] Tibilleti D, Ameiro-Fonseca A, Burch R, Chen Y, Fisher JM, Goguet A, Hardacre C, Hu P, Thompsett D. DFT and In Situ EXAFS Investigation of Gold/Ceria-Zirconia Low-Temperature Water Gas Shift Catalysts: Identification of the Nature of the Active Form of Gold. J. Phys. Chem. B 2005; 109: 22553-22559.

[8] Tabakova T, Boccuzzi F, Manzoli M, Sobczak JW, Idakiev V, Andreeva D. A comparative study of nanosized IB/ceria catalysts for low-temperature water-gas shift reaction. Appl.Catal. A 2006; 298: 127-143.

[9] Kalamaras CM, Gonzalez ID, Navarro RM, Fierro JLG, Efstathiou AM. Effects of Reaction Temperature and Support Composition on the Mechanism of Water-Gas Shift Reaction over Supported-Pt Catalysts. J. Phys. Chem. C 2011; 115: 11595-11610. 
[10] Boaro M, Vicario M, Llorca J, de Leitenburg C, Dolcetti G, Trovarelli A. A comparative study of water gas shift reaction over gold and platinum supported on $\mathrm{ZrO}_{2}$ and $\mathrm{CeO}_{2}-\mathrm{ZrO}_{2}$. Appl. Catal. B 2009; 88: 272-282.

[11] Reina TR, Ivanova S, Delgado JJ, Ivanov I, Tabakova T, Idakiev V, Centeno MA, Odriozola JA. Viability of $\mathrm{Au} / \mathrm{CeO}_{2}-\mathrm{ZnO} / \mathrm{Al}_{2} \mathrm{O}_{3}$ catalysts for pure hydrogen production by the water-gas shift reaction. ChemCatChem 2014; 6: 1401-1409.

[12] Fu Q, Weber A, Flytzani-Stephanopuolos M. Nanostructured $\mathrm{Au}-\mathrm{CeO}_{2}$ Catalysts for LowTemperature Water-Gas Shift. Catal. Lett. 2001; 77: 87-95.

[13] Carter J, Althahban S, Nowicka E, Freakley SJ, Morgan DJ, Shah PM, Golunski S, Kiely CJ, Hutchings GJ. Synergy and Anti-Synergy between Palladium and Gold in Nanoparticles Dispersed on a Reducible Support. ACS Catal. 2016; 6: 6623-6633.

[14] Sagata $\mathrm{K}$, Kaneda $\mathrm{Y}$, Yamaura $\mathrm{H}$, Kobayashi S, Yahiro $\mathrm{H}$. Influence of coexisiting $\mathrm{Al}_{2} \mathrm{O}_{3}$ on the activitiy of copper catalyst for water-gas-shift reaction. Int. J. Hydrogen Energy 2014; 39:20639-20645

[15] Yuan ZY, Idakiev V, Vantomme A, Tabakova T, Ren TZ, Su BL. Mesoporous and nanostructured $\mathrm{CeO}_{2}$ as supports of nano-sized gold catalysts for low-temperature water-gas shift reaction. Catal. Today 2008; 131: 203-210.

[16] Pastor-Pérez L, Buitrago-Sierra R, Sepúlveda-Escribano A. $\mathrm{CeO}_{2}$-promoted Ni/activated carbon catalysts for the water-gas shift (WGS) reaction. Int. J. Hydrogen Energy 2014; 39 : 17589-17599.

[17] Torrente-Murciano L, Gracia-Garcia FR. Effect of nanostructured support on the WGSR activity of $\mathrm{Pt} / \mathrm{CeO}_{2}$ catalysts. Catal. Comm. 2015; 71: 1-6.

[18] Rodriguez JA. Gold-based catalysts for the water-gas shift reaction: Active sites and reaction mechanism. Catal. Today 2011; 160: 3-10.

[19] Leppelt R, Schumacher B, Plzak V, Kinne M, Behm RJ. Kinetics and mechanism of the lowtemperature water-gas shift reaction on $\mathrm{Au} / \mathrm{CeO}_{2}$ catalysts in an idealized reaction atmosphere. J. Catal. 2006; 244: 137-152.

[20] Bond GC, Thompson DT. Catalysis by gold. Catal. Rev. Sci. Eng. 1999; 41: 319-388.

[21] Reina TR, Ivanova S, Centeno MA, Odriozola JA. The role of $\mathrm{Au}, \mathrm{Cu} \& \mathrm{CeO}_{2}$ and their interactions for an enhanced WGS performance. Appl. Catal. B 2016; 187: 98-107. 
[22] Tabakova T, Idakiev V, Papavasiliou J, Avgouropoulos G, loannides T. Effect of additives on the WGS activity of combustion synthesized $\mathrm{CuO} / \mathrm{CeO}_{2}$ catalysts. Catal.Commun. 2007; 8: 101-106.

[23] Gonzalez-Castano M, Reina TR, Ivanova S, Centeno MA, Odriozola JA. Pt vs. Au in watergas shift reaction. J. Catal. 2014; 314: 1-9.

[24] Santos JL, Reina TR, Ivanova S, Centeno MA, Odriozola JA. Gold promoted Cu/ZnO/Al $\mathrm{O}_{3}$ catalysts prepared from hydrotalcite precursors: Advanced materials for the WGS reaction. Appl. Catal. B 2017; 201: 310-317.

[25] Mendes D, Garcia H, Silva VB, Mendes A, Madeira LM. Comparison of nanosize goldbased and copper-based catalysts for the low-temperature water-gas shift reaction. Ind. Eng. Chem. Res. 2009; 48: 430-439.

[26] Pingjun G, Liangfeng C, Qiuyun $Y$, Minghua Q, Hui L, Hexing L, Hualong X, Kangnian F. $\mathrm{Cu} / \mathrm{ZnO} / \mathrm{Al} 2 \mathrm{O} 3$ water-gas shift catalysts for practical fuel cell applications: the performance in shut-down/start-up operation. Int. J. Hydrogen Energy 2009; 34: 2361-2368.

[27] Liu X, Guo P, Xie S, Pei Y, Qiao M, Fan K. Effect of Cu loading on Cu/ZnO water-gas shift catalysts for shut-down/start-up operation. Int. J. Hydrogen Energy 2012; 37: 6381-6388.

[28] Ruettinger W, llinich O, Farrauto RJ. A new generation of water gas shift catalysts for fuel cell applications. J. Power Sources 2003; 118: 61-65.

[29] Xu JF, Ji W, Shen ZX, Tang SH, Ye XR, Jia DZ, Xin XQ. Preparation and characterization of CuO Nanocrystals. J. Solid State Chem. 1999; 147: 516-519.

[30] Spanier JE, Robinson RD, Zhang F, Chan SW, Herman IP. Size-dependent properties of $\mathrm{CeO}_{2-y}$ nanoparticles as studied by Raman scattering. Phys. Rev. B 2001; 64: 25407/1-25407/8 [31] Shishido T, Yamamoto M, Li D, Tian Y, Morioka H, Honda M, Sano T, Takehira K. Watergas shift reaction over $\mathrm{Cu} / \mathrm{ZnO}$ and $\mathrm{Cu} / \mathrm{ZnO} / \mathrm{Al}_{2} \mathrm{O}_{3}$ catalysts prepared by homogeneous precipitation. Appl. Catal. A 2006; 303: 62-71.

[32] Rodriguez JA, Graciani J, Evans J et al. Water-Gas Shift Reaction on a Highly Active Inverse $\mathrm{CeO}_{\times} / \mathrm{Cu}(111)$ Catalyst: Unique Role of Ceria Nanoparticles. Angew. Chem. Int. Ed. 2009; 48: $8047-8050$. 